\title{
HUBUNGAN PAMERAN PENELITIAN DENGAN MOTIVASI PENELITI DALAM MENINGKATKAN POTENSI MENELITI DI BIDANG PERTANIAN
}

\section{RELATIONSHIP OF RESEARCH EXHIBITION WITH MOTIVATION RESEARCH IN RESEARCHING POTENTIAL INCREASE IN FARMING}

\author{
GM Fridani ${ }^{1}$, Sukarelawati², AA Kusumadinata ${ }^{3 a}$ \\ ${ }^{1}$ Alumni Ps. Ilmu Komunikasi, Fakultas Ilmu Sosial dan Ilmu Politik, Universitas Djuanda Bogor, ${ }^{2}$ Dosen \\ Pembimbing I Program Studi Komunikasi, Fakultas Ilmu Sosial dan Ilmu Politik, ${ }^{3}$ Dosen Pembimbing II \\ Program Studi Komunikasi Universitas Djuanda Bogor, Jl. Tol Ciawi No.1 Kotak Pos 35 Bogor 16720 \\ a Korespondensi: Ali Alamsyah Kusumadinata, Email: alialamsyahkusumadinata@gmail.com
}

(Diterima: 07-12-2014; Ditelaah: 10-01-2015; Disetujui: 15-01-2015)

\begin{abstract}
The exhibition is a media and advertising campaign that aims to introduce a product or service to the community with the hope that they are interested in and then buy it. This research was conducted in May 2014 to June 2014 at the Center for Research and Development of Land Resources is located at Cimanggu $12^{\text {th }}$ street Bogor Student Army. Analysis of the variables in this study used quantitative analysis , ie statistics. Once the data was collected completely, the next step was to analyze the data. The results was indicate factor communicator, communication processes, activities exhibition demo, affect the activity exhibition activity. This affects the process, demo exhibits the biological and psychological needs a researchers .

Keywords : Exhebition, Researcher, Comunicator, Process of Communication.
\end{abstract}

\begin{abstract}
Pameran merupakan suatu media promosi dan iklan yang bertujuan memperkenalkan suatu produk atau jasa kepada masyarakat dengan harapan mereka tertarik dan kemudian membelinya. Penelitian ini dilakukan di Balai Besar Penelitian dan Pengembangan Sumberdaya Lahan Pertanian yang beralamat di Jalan Tentara Pelajar No.12 Cimanggu Bogor. Waktu penelitian dilakukan pada bulan Mei 2014 sampai dengan Juni 2014. Analisa variabel dalam penelitian ini digunakan analisa kuantitiatif, yaitu dengan statistik. Setelah data terkumpul dengan lengkap, langkah selanjutnya adalah menganalisis data. Adapun hasil penelitian menunjukkan faktor komunikator, proses komunikasi, kegiatan demo pameran, mempengaruhi kegiatan aktivitas pameran. Hal ini mempengaruhi proses dan demo pameran dalam memenuhi kebutuhan biologis dan psikologis peneliti.

Keyword : Pameren, Peneliti, Komunikator, Proses Komunikasi.
\end{abstract}

GM Fridani, Sukarelawati, AA Kusumadinata. 2015. Hubungan Pameran Penelitian Dengan Motivasi Peneliti Dalam Meningkatkan Potensi Meneliti Di Bidang Pertanian. Jurnal Komunikatio 1(1): 31-39. 


\section{PENDAHULUAN}

Pembangunan pertanian yang maju, efisien dan berkelanjutan, sangat diperlukan sehingga membutuhkan sosialisasi hasil penelitian pertanian yang telah teruji dan disesuaikan dengan kebutuhan masyarakat pengguna. Diseminasi informasi hasil penelitian pertanian yang dilakukan peneliti melalui pameran pembangunan dalam bentuk pameran penelitian merupakan salah satu cara untuk menyebarluaskan informasi hasil penelitian pertanian dengan menggunakan produk dan display sebagai media informasi kepada masyarakat pengguna serta pengunjung pameran, khususnya kepada peneliti lain yang dapat digunakan sebagai studi banding dalam hal penelitian.

Pameran adalah salah satu kegiatan yang menunjukan sesuatu kepada orang banyak mengenai kelebihan dan keunggulan yang dimiliki sesuatu tersebut. Dan secara umum pameran merupakan suatu media promosi dan iklan yang bertujuan memperkenalkan suatu produk atau jasa kepada masyarakat dengan harapan mereka tertarik dan kemudian membelinya (Suranto 2005).

Pameran merupakan usaha mempertunjukan hasil karya, barang, model, contoh, peta, grafik, gambar, benda hidup dan sebagainya secara sistematis pada suatu tempat tertentu untuk menarik perhatian, menggugah hati, membangkitkan keinginan, dan meyakinkan pengunjung sehingga dapat diapresiasi oleh masyarakat luas. Pameran dapat diartikan juga sebagai kegiatan seseorang atau kelompok dalam upaya mempertunjukan suatu hasil karya atau produknya kepada orang lain secara terorganisir. Kegiatan pameran dapat memandu dalam menumbuhkan kesadaran akan nilai-nilai keindahan dan kemampuan kreatifnya sehingga orang lain terpacu untuk berbuat.

Komunikasi dan penyebarluasan informasi hasil penelitian melalui pameran yang merupakan salah satu metode diseminasi tersebut sangat memungkinkan terjadinya komunikasi timbal balik antara penyaji sebagai komunikator, dengan pengunjung yang menerima informasi sebagai komunikan, sehingga diharapkan akhirnya mengakibatkan perubahan ke arah yang lebih baik sesuai sasaran. Proses komunikasi tersebut dapat diartikan sebagai "transfer informasi" atau pesan-pesan dari pengirim pesan sebagai komunikator dan penerima pesan sebagai komunikan. Tujuan dari proses komunikasi tersebut adalah tercapainya saling pengertian (mutual understanding) antara kedua belah pihak (Ruslan 2008).

Menurut pengertian di atas, penyelenggara harus mampu membina suatu hubungan iklim komunikasi yang baik, karena di dalam sebuah organisasi atau instansi pemerintah terdapat suatu struktur didalamnya. Dengan adanya komunikasi dan hubungan antara anggota organisasi instansi yang diharapkan dapat menciptakan pemahaman yang sama terhadap sebuah informasi serta kesamaan pemahaman pada visi dan misi organisasi, sehingga diharapkan akan tercipta suatu hubungan dan motivasi kerjasama agar tujuan tersebut tercapai.

Hasil penelitian tentang informasi teknologi pertanian jarang diketahui oleh masyarakat pengguna, hal tersebut terbukti dari hasil saran peserta dalam pameran sebelumnya yang ditemukan pada interaksi komunikasi antara penyaji, peneliti dan pengunjung di lapangan. Hal ini juga terlihat dari senjang hasil yang dicapai oleh pengguna tentang penelitian dengan hasil yang dicapai oleh lembaga penelitian. Padahal peneliti melalui lembaga telah melakukan upaya penyebarluasan informasi tersebut dengan menggunakan media pameran yang dikemas sedemikian rupa. Hal tersebut dapat dijadikan indikator belum lancarnya penyampaian arus informasi ke masyarakat pengguna.

Pameran penelitian tentang pertanian oleh Balai Besar Penelitian dan Pengembangan Sumberdaya Lahan Pertanian, dilakukan selama 2 kali dalam setahun. Pengunjung ratarata dalam pameran berjumlah 1000 orang, yang terdiri dari 200 orang masyarakat internal dan 800 orang masyarakat eksternal. Sebagaimana tujuan pameran adalah untuk menyebarluaskan informasi tentang hasil-hasil penelitian di bidang pertanian, sekaligus menumbuhkan motivasi pada peneliti agar lebih giat melaksanakan penelitian. Tetapi hasil analisis kegiatan pameran oleh lembaga menunjukkan kurang memotivasi para peneliti untuk lebih giat melakukan penelitian di bidang pertanian. Ada indikasi bahwa kegiatan pameran hanya sebatas pertanggungjawaban lembaga, tetapi kurang dimanfaatkan oleh para peneliti sebagaimana tujuan pameran. 
Rutinitas pameran diharapkan akan ada perubahan ke arah yang lebih baik.

Dengan tuntutan program pengembangan pertanian berkelanjutan, dipastikan peneliti Balai Besar Penelitian dan Pengembangan Sumberdaya Lahan Pertanian memiliki tantangan yang relatif berat. Dari berbagai hambatan yang ditemukan dilapangan, diharapkan melalui program pameran penelitian tersebut dapat dimanfaatkan untuk lebih memotivasi peneliti dalam mengembangkan potensi meneliti di bidang pertanian. Juga diharapkan dapat mendukung program pemerintah yaitu memajukan pembangunan pertanian berkelanjutan, khususnya di Indonesia.

Tujuan dari penelitian ini adalah (1) Seberapa besar pameran penelitian berperan sebagai media komunikasi bagi peneliti, (2) Faktor apa yang mempengaruhi pameran penelitian dalam memotivasi peneliti, (3) Seberapa erat keeratan hubungan antara pameran penelitian dengan motivasi peneliti.

Hasil penelitian ini diharapkan dapat menambah referensi kajian ilmu komunikasi, khususnya tentang kajian pameran dalam mencapai tujuan yang diharapkan oleh lembaga sebagai motif komunikasi. Serta diharapkan dapat dijadikan salah satu bahan masukan bagi pelaksana pameran di Balai Besar Litbang Sumberdaya Lahan Pertanian dalam pengayaan pameran yang baik untuk tercapainya tujuan dari diseminasi informasi hasil penelitian pertanian yang mampu mensukseskan program pertanian berkelanjutan. dan meningkatkan wawasan dan ilmu pengetahuan mengenai diseminasi informasi melalui media pameran, yang diharapkan dapat dimanfaatkan oleh para peneliti guna memotivasi peneliti melakukan penelitian di bidang pertanian di lingkungan Balai Besar Penelitian dan Pengembangan Pertanian Sumberdaya Lahan Pertanian.

\section{Tinjauan Teori}

Muhammad (2009) komunikasi organisasi adalah proses menciptakan dan saling menukar pesan dalam satu jaringan hubungan yang saling tergantung satu sama lain untuk mengatasi lingkungan yang tidak pasti atau selalu berubah-ubah. Komunikasi merupakan hal terpenting dalam organisasi karena setiap organisasi selalu membutuhkan informasi agar komunikasi dapat berjalan dengan efektif.
Karena komunikasi mempunyai peran yang sangat penting dalam organisasi. Komunikasi organisasi sebagai sebuah proses penciptaan dan pengiriman pesan oleh komunikator serta penerimaan dan penafsiran pesan oleh komunikan yang dilaksanakan secara berkelanjutan untuk mencapai tujuan bersama para anggota organisasi (Nasution 2007).

Pameran yang berkelanjutan dilaksanakan oleh Balai Besar Penelitian dan Pengembangan Sumberdaya Lahan Pertanian, merupakan tujuan organisasi bagi peneliti di lingkungan organisasi khususnya, agar dapat meningkatkan motivasi peneliti dalam meningkatkan penelitiannya dibidang pertanian, yang secara tidak langsung diharapkan akan meningkatkan temuantemuan dalam mengembangkan hasil-hasil pertanian. Salah satu kegiatan humas pemerintah yang dapat mendukung pelaksanaan penyebarluasan kebijakan antara pemerintah dengan masyarakat, yaitu melalui kegiatan program pameran pembangunan. Acara promosi melalui pameran akan lebih berhasil memikat para konsumen, jika acara tersebut disertai dengan program humas. Untuk meningkatkan citra secara internal maupun eksternal, maka humas menyelenggarakan pameran sebagai konteks komunikasi.

Suranto (2005) pameran adalah salah satu kegiatan yang menunjukan sesuatu kepada orang banyak mengenai kelebihan dan keunggulan yang dimiliki sesuatu tersebut. Dan secara umum pameran merupakan suatu media promosi dan iklan yang bertujuan memperkenalkan suatu produk atau jasa kepada masyarakat dengan harapan mereka tertarik dan kemudian membelinya. Nasution (2007) Pembangunan merupakan suatu bentuk baru yang memadukan proses sumberdaya manusia dan peningkatan lingkungan dimana orang dapat mengembangkan potensinya untuk menuju kehidupan yang produktif dan kreatif agar tercapai tujuannya. Dengan demikian mendefinisikan pembangunan merupakan suatu proses perubahan sosial dengan partisipasi yang luas dalam suatu masyarakat yang dimaksudkan untuk kemajuan sosial dan material untuk mayoritas rakyat melalui kontrol yang lebih besar yang mereka peroleh terhadap lingkungan mereka. Pembangunan adalah sebagai suatu kegiatan yang berencana dan berkesinambungan untuk meningkatkan taraf hidup masyarakat. Tujuan 
pameran pada akhirnya diharapkan dapat memacu partisipasi peserta guna mengembangkan produktivitas dan kreativitas peserta ke arah yang lebih baik, yaitu peneliti diharapkan memanfaatkan pameran sebagai ajang motivasi untuk meneliti. Untuk itu Balai Besar Penelitian dan Pengembangan Sumberdaya Lahan Pertanian berupaya meningkatkan pelayanan kepada masyarakat untuk mendapatkan informasi guna mendapatkan dan meningkatkan fasilitas dan kesejahteraan yang baik. Karena melaui peningkatan penelitian, secara tidak langsung diharapkan pula para peneliti termotivasi melakukan temuan hingga meningkatkan kemampuan dan taraf hidup lebih baik.

Pameran merupakan bentuk metode penyuluhan yang dapat digunakan dalam memanfaatkan moment yang terjadi di lingkungan sesuai kebutuhan masyarakat. Misalnya pada Hari Kemerdekaan Republik Indonesia, Hari Krida Pertanian, pesta panen raya, pesta laut dan lain-lain. Pada umumnya, masyarakat pedesaan telah mengetahui adanya pameran pada hari-hari penting tersebut dan turut merayakannya dengan mendatangi tempat pameran berlangsung. Dalam rangka menumbuhkan partisipasi masyarakat petani, biasanya dalam pameran Balai Besar Penelitian dan Pengembangan Sumberdaya Lahan Pertanian, masyarakat pengguna diikutsertakan sebagai pendukung dengan mengisi stand-stand yang memperkenalkan hasil-hasil teknologi pertanian yang selama ini telah mereka praktekan.

Maka untuk memanfaatkan rasa antusias masyarakat yang mendatangi pameran penelitian, pameran harus dibuat sedemikian rupa agar masyarakat lebih tertarik pada objek yang dipamerkan. Dengan demikian pelaksanaan pameran perlu direncanakan dengan matang serta perlu diperhatikan media apa saja dan faktor-faktor lain yang mendukung pameran agar pameran menarik minat dan perhatian orang banyak.

Pameran akan bermanfaat bila disajikan dengan menarik perhatian. Berkaitan dengan hal tersebut, humas berpartisipasi kepada pemerintah untuk mengadakan program kegiatan pameran pembangunan, yang bertujuan untuk menginformasikan kepada pengambil kebijakan dan masyarakat pengguna tentang hasil penelitian pertanian agar dapat dimanfaatkan. Hal tersebut tentunya sebagai bentuk dukungan terhadap program pemerintah untuk mencapai pembangunan pertanian yang akan terus berkembang secara berkelanjutan.

Humas pameran adalah pelaksana fungsifungsi humas melalui penyelenggaraan pameran atau ekshibisi. Pada umumnya, pameran dagang atau pameran-pameran terbuka untuk umum merupakan suatu media iklan, karena tujuan penyelenggaraan pameran tersebut adalah untuk memperkenalkan suatu produk kepada masyarakat, agar mereka tertarik kemudian membeli atau memanfaatkannya. Kegiatan humas juga dapat memanfaatkan acara pameran untuk mencapai tujuan-tujuannya. Dan tidak kalah pentingnya adalah hal yang sebaliknya, yakni kegiatankegiatan tersebut juga bermanfaat menunjang keberhasilan dari suatu penyelenggaraan pameran.

Dengan demikian terdapat keterkaitan yang erat antara kegiatan humas dengan acara pameran. Pameran juga merupakan satusatunya media periklanan yang menyentuh semua panca indra; mata, telinga, hidung, lidah, kulit,dan lain-lain. Pameran termasuk jenis metode penyuluhan yang menggunakan pendekatan massal. Melalui pendekatan ini, diharapkan banyak manfaat yang dapat diperoleh dari pelaksanaan pameran, dan diharapkan meningkatkan pengertian dan dapat memberikan ide-ide baru bagi pengunjung khususnya masyarakat pengguna dan berproses untuk perbaikan ke arah yang lebih baik. Peneliti sebagai salah satu sasaran utama bagi lembaga Balai Besar Penelitian dan Pengembangan Sumberdaya Lahan Pertanian, maka pameran diharapkan dapat memberikan manfaat bagi peneliti dan lebih termotivasi untuk meningkatkan hasil-hasil temuan atau penelitiannya di bidang pertanian.

Pameran penelitian pertanian merupakan salah satu cara menyampaikan kemajuan IPTEK di bidang pertanian, meliputi proses, produk, maupun hal-hal lain bersifat spektakuler. Biasanya diselenggarakan secara tematik karena tema pameran biasanya disesuaikan dengan momen-momen tersebut. Hal menarik yaitu materi yang dipamerkan biasanya dipilih yang "langka", atau sedang "booming" untuk menarik para hobeis dan pengunjung mengunjungi stand. Tidak jarang momen pameran dimanfaatkan untuk memperoleh keuntungan secara komersial. 
Sehingga pameran tematik ini menjadi media penyebaran informasi teknologi dan bermultiguna.

Pameran pertanian biasanya insidental dan bersifat sementara (tidak permanen), kecuali lokasi di lahan pertanian. Selain menambah pengetahuan dan wawasan pengunjung, pameran juga dimaksud sebagai "hiburan" pelepas lelah seusai pekerjaan rutin sehari-hari. Pengunjung tidak ditarik karcis masuk ke area pameran. Biasanya pemilihan materi yang dipamerkan, selain sesuai tema, ditentukan oleh sponsor yang mendanai semua persyaratan sebagai peserta pameran. Kegiatan dilakukan secara rutin, seperti misalnya saat ulang tahun (kemerdekaan, kelahiran kota), musim panen (saat anggrek berbunga, mangga berbuah), pertemuan (kongres, kegiatan partai), dan sebagainya, atau insidental, sesuai dengan momen yang tepat di mana banyak pengunjung datang, contoh momen pertemuan ilmiah (seminar, lokakarya, simposium), kunjungan pejabat, atau mencari dana untuk keperluan khusus. Stand-stand yang digelar biasanya adalah stand teknologi, stand pertanian, stand pangan, stand buahbuahan, stand sayuran dan stand sponsor.

\section{MATERI DAN METODE}

Metode yang digunakan dalam penelitian ini adalah metode penelitian korelasional. Metode penelitian korelasi atau korelasional adalah suatu penelitian untuk mengetahui hubungan dan tingkat hubungan antara dua variabel atau lebih tanpa ada upaya untuk mempengaruhi variabel tersebut sehingga tidak terdapat manipulasi variabel (Fraenkel dan Wallen, 2008). Adanya hubungan dan tingkat variabel ini penting karena dengan mengetahui tingkat hubungan yang ada, peneliti akan dapat mengembangkannya sesuai dengan tujuan penelitian. Jenis penelitian ini biasanya melibatkan ukuran statistik/tingkat hubungan yang disebut dengan korelasi (Syamsuddin dan Vismaia, 2009). Penelitian korelasional menggunakan instrumen untuk menentukan apakah, dan untuk tingkat apa, terdapat hubungan antara dua variabel atau lebih yang dapat dikuantitatifkan. Penelitian ini dilakukan di Balai Besar Penelitian dan Pengembangan Sumberdaya Lahan Pertanian yang beralamat di Jalan Tentara Pelajar No.12 Cimanggu Bogor. Waktu penelitian dilakukan pada bulan Mei 2014 sampai dengan Juni 2014.
Teknik pengambilan sampel yang digunakan dalam penelitian ini adalah random sampling. Semua individu dalam populasi baik secara sendiri-sendiri atau bersama-sama diberi kesempatan yang sama untuk dipilih menjadi anggota sampel. Sampel berjumlah 133 peneliti yang ada di Balai Besar Penelitian dan Pengembangan Sumberdaya Lahan Pertanian.

Analisa variabel dalam penelitian ini digunakan analisa kuantitiatif, yaitu dengan statistik. Setelah data terkumpul dengan lengkap, langkah selanjutnya adalah menganalisis data. Menganalisis data merupakan suatu cara yang digunakan untuk menguraikan data yang diperoleh agar dapat dipahami bukan hanya oleh orang yang meneliti, tetapi juga orang lain yang ingin mengetahui hasil penelitian. Berdasarkan pada jenis data yaitu data ordinal serta sifat penelitian yang merupakan korelasi ini, maka untuk mengukur hubungan antar variabel dipergunakan rumus statistik koefisien korelasi tata jenjang Spearman.

\section{HASIL DAN PEMBAHASAN}

\section{Karakteristik Peneliti dalam Mengikuti Pameran}

Balai Besar Litbang Sumberdaya Lahan Pertanian saat ini memiliki pegawai sebanyak 599 orang yang berasal dari berbagai disiplin ilmu dan tingkat pendidikan. Para tenaga S1, S2, dan S3 di Balai Besar Litbang Sumberdaya Lahan Pertanian merupakan lulusan perguruan tinggi baik dari dalam maupun luar negeri. Para tenaga lulusan SLTA, yang saat ini sudah menjadi tenaga menengah terlatih, berasal dari sekolah-sekolah kejuruan dan ditambah dengan pelatihan-pelatihan dalam bidang terkait. Untuk memperlancar pelaksanaan penelitiannya, para peneliti dibantu oleh tenaga teknisi litkayasa, teknisi laboratorium, teknisi pranata komputer, teknisi kearsipan, teknisi komunikasi, pustakawan, dan tenaga administrasi. Jabatan fungsional peneliti lingkup Balai Besar Litbang Sumberdaya Lahan Pertanian secara berurutan adalah Peneliti Utama sebanyak 30 orang, Peneliti Madya sebanyak 58 orang, Peneliti Muda sebanyak 65 orang dan Peneliti Pertama sebanyak 47 orang. Untuk memperlancar pelaksanaan penelitiannya, para peneliti dibantu oleh tenaga teknisi litkayasa pada tingkat keahlian 
Penyelia sebanyak 61 orang dan Pelaksana Lanjutan sebanyak 80 orang.

Komposisi fungsional Peneliti Balai Besar Litbang Sumberdaya Lahan Pertanian yaitu peneliti madya lebih dominan dan berjumlah
$32 \%$, peneliti utama berjumlah $29 \%$, peneliti muda berjumlah $25 \%$ dan peneliti pertama berjumlah $14 \%$.

Adapun karakteristik responden dapat di tampilkan pada Tabel 1.

Tabel 1 Karakteristik Responden Peneliti dalam mengikuti Pameran

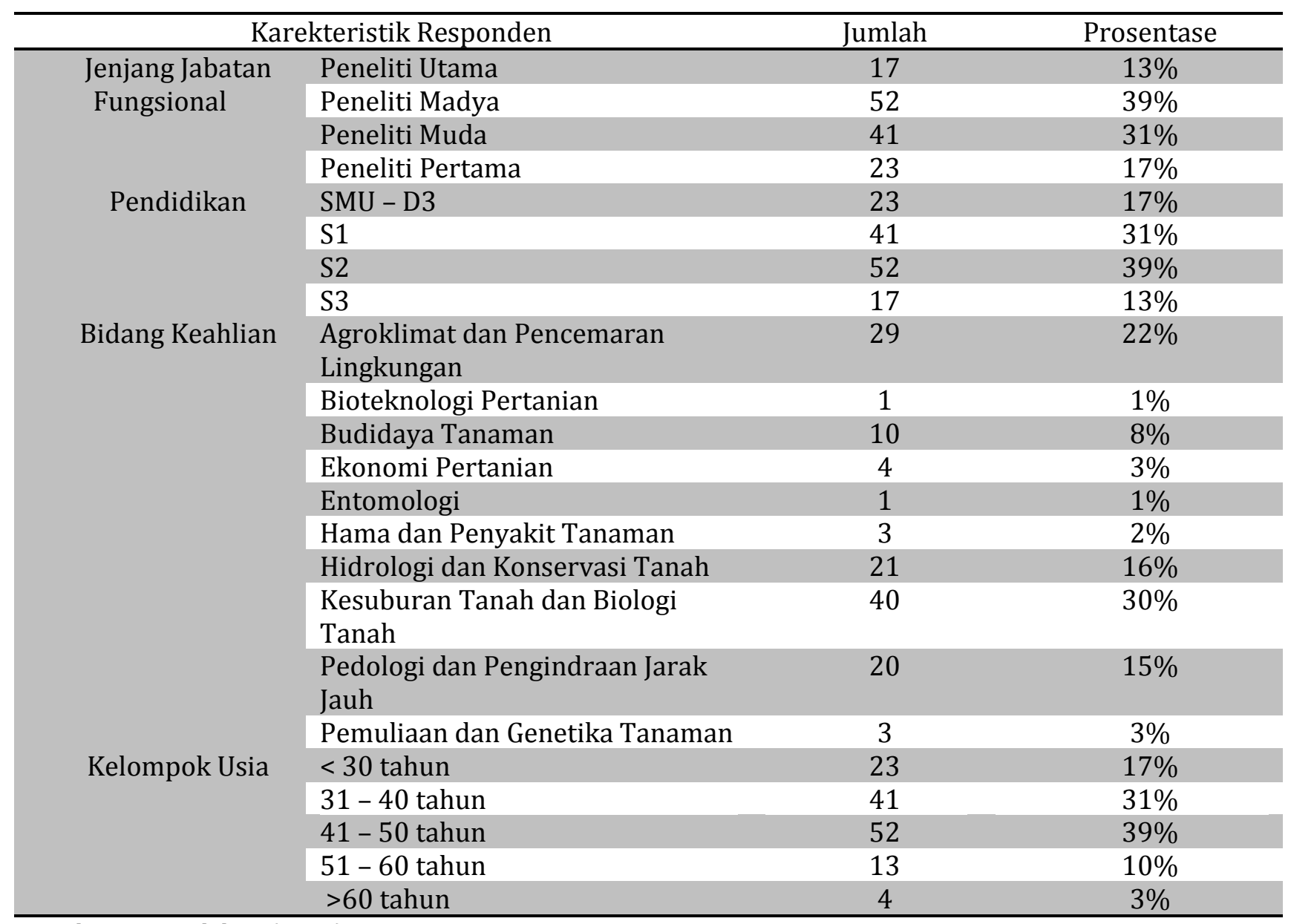

Sumber : Data olahan (2014)

Selain itu adapun peneliti yang mengikuti pameran dalam mensosialisasikan hasil penelitiannya melalui jalur pameran baik teknologi, pertanian serta industri lebih dari
10\% dengan frekuensi lebih dari lima kali pameran. Hal ini dapat ditampilkan pada Tabel 2.

Tabel 2 Frekuensi Pameran yang diikiti oleh peneliti

\begin{tabular}{clcc}
\hline No. & \multicolumn{1}{c}{ Kelompok Usia } & Frekuensi & $\%$ \\
\hline 1 & Pertanian/Perternakan/Perkebunan & 58 & $44 \%$ \\
2 & Industri & 38 & $29 \%$ \\
3 & Teknologi (IT) & 21 & $16 \%$ \\
4 & Otomotif & 16 & $12 \%$ \\
\hline \multicolumn{2}{c}{ Total } & 133 & $100 \%$ \\
\hline
\end{tabular}

Sumber : Data olahan (2014)

Tabel 2, diketahui bahwa jenis pameran yang dikunjungi dalam 2 tahun terakhir oleh seluruh responden adalah untuk jumlah pameran pertanian/ peternakan/ perkebunan sebanyak 
58 kali (44\%), untuk jenis pameran industri yang dikunjungi adalah sebanyak 38 kali (29\%) dalam satu tahun, untuk pameran teknologi (IT) yang dikunjungi adalah sebanyak 21 kali (16\%) dan terakhir pameran berjenis otomatif dikunjungi sebanyak 16 kali (12\%) dalam 2 tahun terakhir.

Sehingga bagi peneliti bahwa mengikuti pameran merupakan sebuah kewajiban bagi peneliti di Balai Besar Litbang Sumberdaya Lahan Pertanian. Kewajiban ini diikuti dengan mendiseminasikan teknologi terbaru dalam meningkatkan kualitas penelitian serta kualitas hasil teknologi tepat guna dari hasil-hasil penelitian.

\section{Faktor-Faktor Yang Mempengaruhi Peneliti dalam Pameran}

Analisis hubungan pameran penelitian terhadap motivasi peneliti diukur berdasarkan kategori Komunikator $\left(\mathrm{X}_{1}\right)$, Proses $\left(\mathrm{X}_{2}\right)$ dan Demo $\left(\mathrm{X}_{3}\right)$ serta kebutuhan psikologis (Y1), kebutuhan Biologis (Y2). Sebaran frekuensi jawaban kepuasan responden terhadap pameran penelitian dianalisis dan diperoleh rataan (means) jawaban dan kemudian diinterpretasikan dengan interval angka penafsiran dalam skala 5 (lima) sangat puas.

Tabel 3 Faktor-faktor yang mempengaruhi peneliti dalam pameran

\begin{tabular}{llcl}
\hline No & \multicolumn{1}{c}{ Variabel } & Skor Penilaian & Keterangan \\
& & & \\
\hline 1 & Komunikator (X1) & 4,65 & Sangat Baik \\
2 & Proses Komunikasi (X2) & 4,39 & Sangat Baik \\
3 & Kegiatan Demo Pameran (X3) & 4,38 & Sangat Baik \\
4 & Kebutuhan Biologis (Y1) & 4,32 & Sangat Baik \\
5 & Kebutuhan Psikologis (Y2) & 4,31 & Sangat Baik \\
\hline
\end{tabular}

Tabel 3 menunjukkan bahwa pada faktor komunikator yang mempengaruhi secara signifikan oleh peneliti atas keefektifan pameran. Selain itu faktor proses komunikasi, demo pameran serta faktor psikologi dari peneliti dalam menyelenggarakan pameran.

Kegiatan pameran merupakan aktivitas penyampaian informasi dari peneliti sebagai komunikator dan pengunjung sebagai

\section{Hubungan antara Pameran Penelitian dan Motivasi Peneliti}

Untuk menentukan ada tidaknya hubungan antara pameran penelitian dengan motivasi peneliti dalam meningkatkan potensi meneliti dibidang pertanian, maka perlu dilakukan pengujian hipotesis. Untuk itu terlebih dahulu dihitung nilai koefisien antara pameran penelitian dengan motivasi peneliti. Penulis responden. Kegiatan ini dilakukan dalam bentuk demo pameran sebagai mediasi. Pengunjung melakukan visibilitas serta tanya jawab atas teknologi yang dihasilkan yang dapat diterapkan. Oleh karena itu faktor kunci nya adalah pada komunikator yang merupakan bagian dari proses komunikasi yang penting untuk menyatakan informasi teknologi ke komunikan.

menggunakan rumus korelasi Rank Spearman berganda.

Sebagai persiapan untuk menghitung koefisien maka terlebih dahulu dibuat tabel silang untuk mengetahui hubungan antara variabel $x$ (pameran penelitian) dengan variabel y (motivasi peneliti) dapat dilihat pada tabel berikut: 
Tabel 4. Hubungan Pameran dengan Motivasi Peneliti

\begin{tabular}{lcc}
\hline \multicolumn{1}{c}{ Pameran } & \multicolumn{2}{c}{ Motivasi Peneliti } \\
\cline { 2 - 3 } penelitian & Kebutuhan Biologis & Kebutuhan Psikologis \\
Komunikator &, $251^{* *}$ &, 117 \\
Proses &, $173^{*}$ &, $602^{* *}$ \\
\hline Demo &, $206^{*}$ & \\
\hline ** berhubungan nyata pada taraf 0,01 & \\
*berhubungan nyata pada taraf 0,05 &
\end{tabular}

Berdasarkan data pada Tabel 4, dapat dinyatakan bahwa hubungan variabel pameran penelitian yang diuraikan dalam beberapa kategori memiliki hubungan yang nyata pada taraf 0,01 dan 0,05 dengan variabel motivasi peneliti.

Variabel komunikator berkorelasi positif dengan variabel kebutuhan biologis dimana info guide yang memberikan informasi dengan tatanan bahasa yang baik dan disertai dengan keluasan wawasan yang dimiliki oleh seorang info guide menunjang keterampilan dalam menindaklanjuti semua permintaan dan pelayanan dari pengunjung telah memenuhi kebutuhan biologis responden dalam meningkatkan motivasi responden untuk melakukan penelitan.

Variabel proses berkorelasi positif dengan kebutuhan biologis dan kebutuhan psikologis responden. Materi yang disampaikan secara verbal oleh info guide yang disertai dengan faktor pendukung pesan serta kemampuan info guide memberikan penjelasan dan infomasi yang sesuai dengan tema produk yang dihasilkan memunculkan motivasi bagi para peneliti untuk melakukan penelitian, karena dengan dilakukannya penelitian maka peneliti memiliki kesempatan mengembangkan karir bagi responden, guna mengembangkan potensi diri serta meningkatkan jenjang karier di lingkungan kerjanya. Selain itu, proses dari pelaksanaan suatu pameran penelitian dapat menciptakan pembagian tugas/pekerjaan yang ditetapkan secara formal melalui struktur organisasi, memotivasi untuk segera menyelesaikan pekerjaan dan timbulnya perubahan dan perbaikan yang dapat memaksimalkan responden dalam melakukan penelitian guna mencapai tujuan organisasi.

Pada kategori demo pameran berkorelasi positif dengan kebutuhan biologis dan kebutuhan psikologis responden. Adanya alat demo dalam pameran penelitian yang bertujuan untuk memperkenalkan produk teknologi terbaru membuat responden memotivasi diri untuk mengembangkan potensi diri dalam meneliti. Selain itu adanya demo dalam pameran penelitian memicu diri responden untuk dapat meningkatkan kemampuan peneliti dalam pencapaian target kerja dan mengambangkan potensi diri untuk eksis dalam pekerjaan secara individu maupun kelompok.

Adapun uji hipotesis yang telah dilakukan maka di hasilkan uji Spearman berganda sebesar 0,306. Berdasarkan pedoman interpretasi koefisien korelasi Sugiyono (2000) dan hasil perhitungan uji korelasi Rank Spearman berganda, yang diperoleh angka koefisien korelasi sebesar 0,306, dan seperti yang tertera dalam tabel bahwa kategori rendah berada pada angka 0,20 - 0,0399, maka dapat diartikan bahwa hubungan antara variabel $X$ (pameran penelitian) dengan variabel Y (motivasi peneliti) berada dalam kategori rendah.

Selanjutnya untuk menguji keeratan (signifikasi) hubungan tersebut, dipergunkan rumus sebagai berikut:

$$
\begin{aligned}
& \mathrm{t}=r \sqrt{\frac{n-2}{1-r^{2}}} \\
& \mathrm{t}=0,3068 \sqrt{\frac{133-2}{1-(0,3068)^{2}}} \\
& \mathrm{t}=3,876
\end{aligned}
$$

Berdasarkan hasil penghitungan nilat $t$ diperoleh $t_{\text {hitung }}=3,876$. Selanjutnya dicari $t_{\text {tabel }}$ untuk taraf kesalahan 0,05 uji dua pihak dengan $\mathrm{dk}=133-2=131$, maka dengan menggunakan $t_{\text {tabel }}$ berdasarkan perhitungan excell diperoleh nilai $t_{\text {tabel }}$ adalah 1,978. Setelah diketahui nilai selanjutnya $t_{\text {hitung }}$ tersebut dibandingkan dengan $t_{\text {tabel. }}$. Diperoleh nilai $t_{\text {hitung }}$ lebih besar dibandingkan $t_{\text {tabel, }}$ yaitu $3,876>1,978$. 
Berdasarkan hasil perhitungan dan ditunjukan oleh kurva diatas, maka dapat dinyatakan bahwa $t_{\text {hitung }}$ jatuh pada daerah penolakan $\mathrm{H}_{0}$, maka dapat dinyatakan hipotesa nol yang menyatakan bahwa tidak ada hubungan antara pameran penelitian dengan motivasi peneliti ditolak, sehingga hipotesis alternatif diterima. Dengan demikian dapat disimpulkan bahwa hubungan antara pameran penelitian dengan motivasi peneliti sebesar 0,306 adalah positif. Analisis korelasi dapat dilanjutkan dengan menghitung koefisien determinasi untuk mencari besarnya hubungan antara pameran penelitian dengan motivasi peneliti dapat ditentukan dengan perhitungan koefisien determinasi dengan rumus:

$$
\begin{aligned}
& \mathrm{Kd}=\mathrm{rs}^{2} \times 100 \% \\
& \mathrm{Kd}=0,306792 \times 100 \% \\
& \mathrm{Kd}=9,41 \%
\end{aligned}
$$

Berdasarkan hasil perhitungan koefisien determinasi diperoleh hasil sebesar 9,41\%. Hasil perhitungan ini dapat diartikan bahwa pameran penelitian berkontribusi sebesar 9,41\% terhadap motivasi peneliti untuk melaksanakan penelitian Sedangkan selebihnya dipengaruhi oleh variabel lainnya sebesar $90,59 \%$.

\section{KESIMPULAN DAN SARAN}

\section{Kesimpulan}

Berdasarkan hasil penelitian yang dilakukan maka kesimpulannya adalah :

Pameran Penelitian dikaji melalui 3 (tiga) kategori yaitu Komunikator $\left(X_{1}\right)$, Proses $\left(X_{2}\right)$ dan Demo $\left(\mathrm{X}_{3}\right)$. Pada kategori komunikator $\left(\mathrm{X}_{1}\right)$, diperoleh sebesar 4,651 dan berada pada kategori sangat baik, Pada kategori Proses $\left(\mathrm{X}_{2}\right)$, diperoleh sebesar 4,39 dan berada pada kategori sangat baik. Dan kategori Demo $\left(\mathrm{X}_{3}\right)$, diperoleh sebesar 4,38 dan berada pada kategori sangat baik. Motivasi Peneliti dikaji melalui 2 (dua) variabel yaitu Kebutuhan Biologis $\left(\mathrm{Y}_{1}\right)$ dan Kebutuhan Psikologis $\left(\mathrm{Y}_{2}\right)$. Pada variabel Kebutuhan Biologis $\left(\mathrm{Y}_{1}\right)$, diperoleh sebesar 4,32 dan berada pada kategori sangat baik. Adapun variabel kebutuhan psikologis $\left(\mathrm{Y}_{2}\right)$, diperoleh sebesar
4,31 dan berada pada kategori sangat baik. Adapun uji hipotesis hubungan antara pameran penelitian dengan motivasi peneliti diperoleh hasil 0,3068 dan berada pada kategori rendah yang berarti tidak hanya faktor psikologis dan biologi namun terdapat faktor lain yang mempengaruhi faktor yang peneliti dalam mengikuti pameran.

\section{Saran}

Saran yang dapat diberikan adalah :

1. Perlunya meningkatkan penyelenggaraan pameran penelitian pertanian dengan pengayaan yang lebih baik dan menarik dan sesuai dengan kepentingan, agar peneliti termotivasi untuk mengembangkan potensi menelitinya.

2. Perlunya dilakukan penelitian lebih lanjut yang membahas tentang faktor-faktor yang dapat mempengaruhi pameran penelitian dalam memotivasi peneliti di Balai Besar Litbang Sumberdaya Lahan Pertanian dalam meningkatkan potensi menelitinya.

3. Perlunya meningkatkan dan mempertahankan motivasi peneliti dalam mengembangkan potensi meneliti di bidang pertanian.

\section{DAFTAR PUSTAKA}

Fraenkel JR dan Wellen NE. 2008. How to Design and Evaluate research in Education. New York: McGraw-Hill.

Muhammad A. 2009. Komunikasi Organisasi. Jakarta : Bumi Aksara.

Nasution, Zulkarimen. 2007. Komunikasi Pembangunan, Pengenalan Teori dan Penerapannya. Jakarta: PT. Raja Grafindo Persada.

Ruslan R. 2008. Management Public Relations dan Media Komunikasi, Konsepsi dan Aplikasinya. Edisi Revisi. Jakarta : PT.Raja Grafindo Persada.

Syamsuddin dan Vismaia SD. (2009). Metodologi Penelitian Pendidikan Bahasa. Bandung: PT Remaja Rosdakarya.

Suranto AW. 2005. Komunikasi Perkantoran. Yogyakarta: Media Wacana. 